\title{
IMPACT OF PHYTOREMEDIATION AND BIOAUGMENTATION ON MICROBIAL COMMUNITY IN OIL SHALE CHEMICAL INDUSTRY SOLID WASTE
}

\author{
Jaak Truu \\ Jaanis Juhanson \\ Eeva Heinaru \\ Eve Vedler \\ Merike Merimaa \\ Ain Heinaru \\ University of Tartu, Estonia
}

\begin{abstract}
Field and laboratory experiments were carried out in order to estimate the suitability of phytoremediation and bioaugmentation for oil shale chemical industry solid waste (semicoke) dump area remediation as well as influence of plants and laboratory selected degradative bacterial strains on the microbial communities in semi-coke. Field test plots (each $50 \mathrm{~m}^{2}$ ) were established at semi-coke depository in July 2001 and samples for microbiological and chemical analysis were collected in October 2002 and 2003. Microbial communities in semi-coke were analysed using both culture-based and molecular methods. Changes in microbial community structure and activity occurred in semi-coke as a result of phytoremediation and bioaugmentation. Phytoremediation increased the number of oildegrading bacteria and diversity of microbial community in semi-coke as well as microbial biomass. A comparison of $16 \mathrm{~S}$ rRNA gene-based DGGE fingerprints of semi-coke samples using multivariate analysis showed variation between the bacterial community profiles from different treatments. Degradation rates of pollutants did not differ significantly between plots with vegetation except for sod, showing negligible effect of soil amendment typeon biodegradation activity. Our results indicate that increased biodegradation activity was due to proliferation of specific microbial groups, changes in taxonomic and metabolic diversity of bacterial community and shifts in the structure of catabolic genes. Based on our findings we conclude that phytoremediation and bioaugmentation could be considered as an alternative management option for remediation of oil shale solid waste.
\end{abstract}

\section{KEYWORDS}

Bioaugmentation; Oil shale chemical industry; Phytoremediation; Microbial community

\section{INTRODUCTION}

In Estonia about 3 million tons of oil shale is treated thermally to produce oil annually and the solid waste of this process, called semi-coke is disposed of to ash-dump. As a result of oil 
shale thermal processing during last decades huge dump sites of the semi-coke have been formed in the areas surrounding oil shale chemical industry plants in northeastern part of Estonia. The semi-coke mounds cover an area about 200 ha and contain up to 100 million tons of solid waste. Semi-coke solid wastes contain several organic and inorganic compounds (oil products, asphaltenes, phenols, PAHs, sulfuric compounds), while liquid wastes (leachate) from depository area are characterized by high concentration of oil products, phenol, cresols, dimethylphenols and resorcinols. The liquid pollution from semi-coke dump area deteriorates surface water as well as the underlying aquifers [1].

Phytoremediation is a new emerging environmental technology for removal of contaminants from the environment. This approach is based on the combined action of plants and their associated microbial communities to degrade, remove, inactivate or immobilize toxic compounds in soil. Plants may act directly accumulating (phytoaccumulation) and in some cases metabolising (phytodegradation) pollutants [2], but one way to achieve truly in situ bioremediation is to perform rhizosphere bioremediation by utilizing plants (rhizodegradation or phytoremedition explanta) [3]. Sometimes rhizodegradation defined as degradation of contaminants in root zone due to both microbial activity and roots [4]. Vegetation facilitates bioremediation of contaminated soils due to increased microbial activity, population density and diversity on the surface and in the vicinity of root. During rhizoremediation, exudates derived from the plant roots stimulate activity of bacteria in soil resulting in a more efficient degradation of pollutants. The degradation of pollutants during phytoremediation can be enhanced by adding to the soil specific microorganisms, able to degrade the certain pollutants [5]. Phytoremediation has been proposed as an efficient, low-cost remediation technique to restore areas contaminated with chlorinated solvents, BTEX compounds, phenols and PAHs. The aim of current study was to assess the response of soil microbial community to the phytoremediation in combination with bioaugmentation.

\section{MATERIAL AND METHODS}

\subsection{Phytoremediation experiment}

Four test plots (each $50 \mathrm{~m}^{2}$ ) were established at semi-coke depository in July 2001. Plant treatment was based on a grass mixture of four species (Lolim perenne - perennial ryegrass), Poa pratensis - Kentucky bluegrass, Festuca rubra - red fescue, and Festuca ovina - blue fescue). In addition to plants, four different treatments were utilized. The following treatments were applied: plot 1 - no treatment (grass seeds in semi-coke), plot 2 - seeds in semi-coke were covered by sand layer $(1-2 \mathrm{~cm})$, plot 3 - seeds in semi-coke were covered by peat layer (1-2 cm), plot 4 - semi-coke was covered with the layer of sod (pre-grown lawn). In October 2001, 2002 and 2003 soil sampling was performed on treatment plots and control area. We analyzed semi-coke samples collected from the test plots at the depository area for chemical and microbiological parameters.

\subsection{Bioaugmentation experiment}

For the bioaugmentation experiment the set of bacteria consisting of three strains isolated from nearby polluted area was selected. These three bacterial strains Pseudomonas mendocina PC1, P. fluorescens PC24 and P. fluorescens PC18 degrade phenols via catechol meta, catechol or protocatechuate ortho or via the combination of catechol meta and protocatechuate ortho pathways, respectively [6]. In bioaugmentation experiments the biomass of these bacteria was supplied to the part experimental plots (each $10 \mathrm{~m}^{2}$ ) in July 
2002. Each treatment received $20 \mathrm{~L}$ of bacterial suspension with concentration $10^{8} \mathrm{CFU} \mathrm{ml}-\mathrm{t}$. The ratio of bacterial strains PC1, PC18 and PC24 was in suspension 3:1:1.

\subsection{Microbiological methods}

The microbial communities were removed from semi-coke and plant root surface by vortexing in sterile tap water. Heterotrophic plate count was enumerated by the spread plate method in triplicate on R2A agar (Difco). The number of phenol-degrading bacteria was determined in triplicate sets on M9-salts agar plates supplemented with trace elements and phenol $(2,5 \mathrm{mM})$. The most probable number (MPN) technique was used to count alkane degrading bacteria in Bushnell-Haas medium on microtiter plates with $\mathrm{n}$-hexadecane. The heterotrophic activity and diversity of microbial community was measured using Biolog EcoPlates (Biolog, Inc.). Results of Biolog profiles are presented as total activity (summed well color development of all 31 wells) and by Shannon diversity index. Color development data of Biolog EcoPlates was also subject to kinetic data analysis according to method of Lindstrom et al. [7].

$$
\sum O D_{590}=\frac{K}{\left(1+e^{-r(1-s)}\right)}
$$

The method provides two kinetic parameters $\mathrm{K}$ and $\mathrm{r}$ that are invariant with respect to inoculum density, and reflect the composition of cultivable microbial communities. In order to estimate statistical significance, an ANOVA on the model parameters $\mathrm{K}$ and $\mathrm{r}$ from each treatment regression was performed. Microbial biomass carbon was measured by fumigationextraction technique. Microbial DNA was extracted from soil samples with UltraClean Mega Soil DNA kit (Mo Bio Laboratories, Inc.). Bacterial community structure was assessed with primer pair 318f-GC/535r [8]. A denaturating gradient gel electrophoresis (DGGE) system DCode (Bio Rad, Inc.) was used to separate the amplified gene fragments. DGGE gels were digitized and banding pattern analysed using Principal Coordinate Analysis (PCoA).

\section{RESULTS}

Semi-coke is characterized by high organic carbon content, nearly half of which consists of asphaltenes. After retorting at $500{ }^{\circ} \mathrm{C}$, processed oil shale is highly saline, alkaline, biologically sterile, nutrient deficient material with no structure. The semi-coke contains nalkanes and PAHs, but the concentrations of these compounds is relatively low (maximum individual alkane concentrations ca. $8 \mu \mathrm{g} \mathrm{g}^{-1}$ and maximum individual PAH concentrations ca. $20 \mu \mathrm{g} \mathrm{g}^{-1}[9]$.

The chemical analysis of soil samples showed impact of the plant treatment on degradation rate of pollutants. Within a two and half year period starting from the establishment of test plots in July 2001, the concentration of volatile phenols was reduced up to $100 \%$, the concentration of oil products more than three times (from $340 \mathrm{mg} \mathrm{kg}^{-1}$ to $100 \mathrm{mg} \mathrm{kg}^{-1}$ ), and the total content of organic carbon decreased by 10 to $30 \mathrm{~g}$ per $\mathrm{kg}$ (from $15 \%$ to $12 \%$ ). The degradation rate was highest on the plots with peat amendment and sod with the highest root density in semi-coke. In upper layer samples $(0-10 \mathrm{~cm})$ the reduction of oil products and phenols was even bigger being in the range from $83 \%$ to $98 \%$.

Bacterial biomass consisting of three bacterial strains was applied to three experimental plots in June 2002. Within a three months period the concentration of residual oil shale oil in semi- 
coke decreased by $13.6 \%$ to $53.6 \%$ on plots treated with bacterial biomass compared to untreated parts of experimental plots. Bioaugmentation increased the root biomass and length. The plant treatment increased the number of phenol-degrading bacteria by order of magnitude, while the number of heterotrophic aerobic bacteria remained on the same level compared to the untreated plot. Samples from the second year (2002) showed lower values of aerobic heterotrophic bacteria than in year 2001, which could be due to extremely dry vegetation period. During the three year monitoring period the general trend was the increase of proportion of biodegradable bacterial numbers within microbial community due to the plant treatment as well as increase in microbial biomass (Table 1). Highest values for all measured microbiological parameters were found in rhizosphere samples. While bacterial total numbers increased by order of magnitude compared to control, the number of phenoldegrading bacteria was more than 100 times higher in the rhizospheric soil. The highest values for microbial activity and diversity measured with Biolog EcoPlates were recorded in rhizosphere samples. Addition of bacterial biomass to semi-coke resulted in rise of both absolute number (up to $7.8 \times 10^{6} \mathrm{CFU} \mathrm{g}^{-1}$ ) and relative abundance (up to $30 \%$ ) of phenoldegrading bacteria in the studied samples in year of application, while these values drop down to level of untreated plots next year.

Table 1. Microbiological properties of soil from different treatment plots on year 2003.

\begin{tabular}{lcccc}
\hline Treatment & $\begin{array}{c}\text { Microbial } \\
\text { biomass } \\
\left(\mu \mathrm{g} \mathrm{g}^{-1} \mathrm{dw}\right)\end{array}$ & $\begin{array}{c}\text { Aerobic } \\
\text { heterotrophic } \\
\text { bacteria } \\
\left(\mathrm{CFU} \mathrm{g}^{-1} \mathrm{tw}\right)\end{array}$ & $\begin{array}{c}\text { Phenol } \\
\text { degrading } \\
\text { bacteria } \\
\left(\mathrm{CFU} \mathrm{g}^{-1} \mathrm{dw}\right)\end{array}$ & $\begin{array}{c}\text { Alkane } \\
\text { degrading } \\
\text { bacteria } \\
\left(\mathrm{CFU} \mathrm{g}^{-1} \mathrm{dw}\right)\end{array}$ \\
\hline Control & 1070 & $3.7^{*} 10^{6}$ & $4.9^{*} 10^{5}$ & $2.2^{*} 10^{3}$ \\
Control with biomass & 1380 & $8.4^{*} 10^{6}$ & $7.2^{*} 10^{5}$ & $2.2^{*} 10^{3}$ \\
Grass & 2600 & $1.8^{*} 10^{7}$ & $1.8^{*} 10^{6}$ & $7.0^{*} 10^{3}$ \\
Grass and sand layer & 1510 & $7.4^{*} 10^{6}$ & $2.1^{*} 10^{5}$ & $1.9^{*} 10^{3}$ \\
Grass and peat layer & 1670 & $9.4^{*} 10^{6}$ & $5.6^{*} 10^{4}$ & $3.1^{*} 10^{3}$ \\
Grass and peat layer with biomass & 1360 & $6.0^{*} 10^{6}$ & $5.5^{*} 10^{5}$ & $4.6^{*} 10^{3}$ \\
Sod & 1720 & $5.5^{*} 10^{6}$ & $1.8^{*} 10^{6}$ & $6.3^{*} 10^{3}$ \\
Sod with biomass & 1550 & $1.8^{*} 10^{7}$ & $1.6^{*} 10^{6}$ & $1.2^{*} 10^{4}$ \\
\hline
\end{tabular}

We compared microbial communities from different treatments using kinetic model based on summed well color development of Biolog EcoPlates (Table 2). Model parameters estimated from these fitted curves were statistically different (ANOVA) both in 2002 and 2003 $(\mathrm{P}<0.001)$, indicating changes in microbial community structure due to plant treatment and bioaugmentation. Like in case of microbial numbers the differences between bioaugmented and non-treated vegetated plot microbial community kinetic parameters $\mathrm{K}$ and $\mathrm{r}$ were bigger in the year of biomass application compared to values obtained year later.

A comparison of $16 \mathrm{~S}$ rRNA gene-based DGGE fingerprints of soil samples using multivariate analysis showed variation between the bacterial community profiles from different treatments. According to PCoA plot (Figure 1) the bacterial communities from bioaugmented plots with sod and peat cover are most distinct from the control plot. 
Table 2. Comparison of kinetic model parameters for summed well color development of Biolog EcoPlates for years 2002 and 2003.

\begin{tabular}{lccccc}
\hline Sample & Year & $\mathrm{K}$ & $\mathrm{r}$ & $\mathrm{S}(\mathrm{h})$ & $\mathrm{R}^{2}(\%)$ \\
\hline Control & 2002 & $8.8 \pm 2.7$ & $0.045 \pm 0.007$ & $117.8 \pm 13.5$ & 99.8 \\
& 2003 & $4.5 \pm 0.2$ & $0.031 \pm 0.002$ & $110.4 \pm 3.2$ & 99.5 \\
Control with biomass & 2002 & $5.5 \pm 0.2$ & $0.061 \pm 0.005$ & $90.6 \pm 2.1$ & 99.8 \\
& 2003 & $11.6 \pm 0.6$ & $0.032 \pm 0.003$ & $104.6 \pm 4.9$ & 99.8 \\
Grass and peat layer & 2002 & $29.1 \pm 1.0$ & $0.060 \pm 0.004$ & $75.3 \pm 1.8$ & 99.8 \\
& 2003 & $22.2 \pm 0.7$ & $0.060 \pm 0.006$ & $66.0 \pm 2.1$ & 99.0 \\
Grass and peat layer with biomass & 2002 & $40.8 \pm 1.0$ & $0.070 \pm 0.006$ & $56.8 \pm 1.5$ & 99.7 \\
& 2003 & $28.7 \pm 0.7$ & $0.034 \pm 0.004$ & $83.9 \pm 3.4$ & 98.0 \\
\hline
\end{tabular}

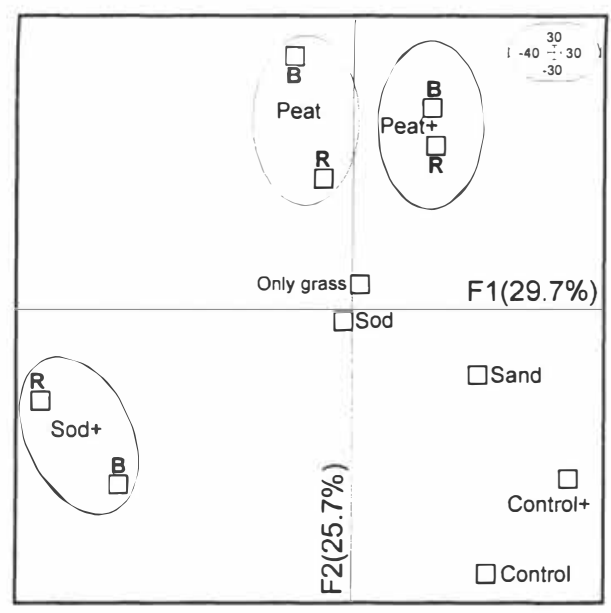

Figure 1. Ordination of bacterial communities based on Principal Coordinate Analysis of DGGE fingerprints. Plus at the end of treatment type indicates bioaugmentation.

Application of sand layer with vegetation to semi-coke gave the rise to less altered bacterial community profile compared to untreated plot. The PCoA plot also indicates that shifts in bacterial community structure due to bioaugmentation are opposite in case of sod and peat amendment.

\section{DISCUSSION}

Biodegradation processes of organic pollutants in semi-coke are more difficult to achieve than those in natural soils. High initial $\mathrm{pH}$ value, elevated concentration of $\mathrm{Ca}$ and $\mathrm{Mg}$ as well as sulfuric compounds limit microbial activity in semi-coke. Another group of factors affecting 
the biodegradation activity is susceptibility of organic pollutants to microbial attack. Among organic compounds found in semi-coke, asphaltenes are the most resistant fraction for bioremediation $[10,11]$.

Asphaltenes are also known for the inhibition of some physiological groups of microorganisms in soil like actinomycetes as well as microbes participating in the processes of nitrogen and phosphorous transformations [12].

Degradation rates of pollutants did not differ significantly between plots with vegetation except for sod, showing negligible effect of soil amendment type during study period. This suggests that establishment of vegetation on semi-coke was a key factor for acceleration of degradation of pollutants. Phytoremediation had a substantial impact on bacterial numbers, activity, biomass and diversity in semi-coke. Analysis of $16 \mathrm{~S}$ rDNA DGGE fingerprints shows that the effect of phytoremediation is not associated only with rhizosphere soil, but plant treatment affiected the microbial community structure in bulk soil.

Enhancement of pollutant degradation rate using bioaugmentation has been successfully applied in several cases with non-vegetated soil [13] and planted soil [14]. Typically during the time course of bioaugmentation process the improvement of the bioremedation activity and increase of microbial counts is temporary and return to initial values is observed. The same kind of time dynamics of measured microbial community parameters was observable in our experiments. Our data do not give evidence what was the mode of action of bioaugmentation in case of semi-coke - transfer of catabolic genes (plasmid-mediated bioagmentation) or survival of introduced strains. Further research is needed to identify the mechanism how inoculation enhances degradation of pollutants in semi-coke.

\section{CONCLUSIONS}

Our results indicate that increased biodegradation activity was due to proliferation of specific microbial groups, changes in taxonomic and metabolic diversity of bacterial community and shifts in the structure of catabolic genes. Based on our findings we conclude that phytoremediation and bioaugmentation could be considered as an alternative management option for remediation of oil shale solid waste.

\section{ACKNOWLEDGEMENTS}

The study was funded by the Maj and Tor Nessling Foundation and by the Estonian Science Foundation grant No 5682 .

\section{REFERENCES}

[1] Truu, J., Heinaru, E., Talpsep, E., Heinaru, A., 2002. Analysis of river pollution data from low-flow period by means of multivariate techniques: A case study from the oilshale industry region, northeastern Estonia. Environmental Science and Pollution Research 1, 8-14.

[2] White, P., 200 lt Phytoremediation assisted by microorganims. Trends Plant Sci. 6, 502 p.

[3] Alkorta, I., and Garbisu C., 2001, Phytoremediation of organic contaminants in soil. Bioresource Technology 79, 273-276. 
[4] Trapp, S., and Karlson, U., 200 lt Aspects of phytoremediation of organic pollutants. $J$. Soils Sediments $137-43$.

[5] Kuiper, I., Lagendijk, E.L., Bloemberg, G.V., Lugtenberg, B., 2004. Rhizoremediation: A beneficial plant-microbe interaction. Molecular Plant-Microbe Interactions 17, 6-15.

[6] Heinaru, E., Truu, J., Stottmeister, U., Heinaru, A., 2000. Three types of phenol and pcresol catabolism in phenol- and p-cresol-degrading bacteria isolated from river water continuously polluted with phenolic compounds. FEMS Microbiology Ecology 31,195205.

[7] Lindstrom, J.E., Barry, R.P., Braddock, J.F., 1998. Microbial community analysis: a kinetic approach to constructing potential C source utilization patterns. Soil Biol. Biochem. 30, 231-239.

[8] Schäfer, H., and Muyzer, G., 2001t Methods in Microbiology. Academic Press, London, pp. 425-468.

[9] Kronholm, J., Kettunen, J., Hartonen, K., Riekkola, M.L., 2004. Pressurised hot water extraction of $n$-alkanes and polyaromatic hydrocarbons in soil and sediment of from oil shale industry district in Estonia. J. Soils Sediments 4, 107-114.

[10] Mana Capelli, S. M., Busalmen, J.P, de Sanchez, S.R., 200 lt Hydrocarbon bioremediation of a mineral-base contaminated waste from crude oil extraction by indigenous bacteria. International Biodeterioration \& Biodegradation 47, 233-238.

[11] Peressuttia, S.R., Alvarez, H.M.,. Pucci, O.H., 2003. Dynamics of hydrocarbondegrading bacteriocenosis of an experimental oil pollution in Patagonian soil. International Biodeterioration \& Biodegradation 52, $21-30$.

[12] Muratova, A., Hübner, T., Narula, N., Wand, H., Turkovskaya, O., Kuschk, P., Jahn, R., Merbach, W., 2003. Rhizosphere microflora of plants used for the phytoremediation of bitumen-contaminated soil. Microbiological Research 158, 151-161.

[13] Ruberto, L., Vazquez, S,C., Mac Cormack, W.P., 2003. Effectiveness of the natural bacterial flora, biostimulation and bioaugmentation on the bioremediation of a hydrocarbon contaminated Antartic soil. International Biodeterioration \& Biodegradation 52, 115-125.

[14] Singer, A.C., Smith, D., Jury, W.A., Hathuc, K., Crowley, D.E., 2003. Impact of the plant rhizosphere and augmentation on remediation of polychlorinated biphenyl contaminated soil. Environmental Toxicology and Chemistry 22, 1998-2004. 